\title{
The rhizobiome of herbaceous plants in Clovelly and Sterkspruit soils of the Stevenson-Hamilton supersite
}

\begin{tabular}{|c|c|}
\hline $\begin{array}{l}\text { Authors: } \\
\text { Marcele Verm } \\
\text { Errol D. Cason } \\
\text { Wijnand J. Sw }\end{array}$ & $\begin{array}{l}\text { eulen }{ }^{1} \text { (D) } \\
\operatorname{art}^{3} \text { (D) }\end{array}$ \\
\hline $\begin{array}{l}\text { Affiliations: } \\
{ }^{1} \text { Microbial Bio } \\
\text { Food Biotechn } \\
\text { Department, } \\
\text { Natural and A } \\
\text { Sciences, Univ } \\
\text { Free State, Blo } \\
\text { South Africa }\end{array}$ & $\begin{array}{l}\text { chemical and } \\
\text { ology } \\
\text { aculty of } \\
\text { gricultural } \\
\text { ersity of the } \\
\text { emfontein, }\end{array}$ \\
\hline $\begin{array}{l}{ }^{2} \text { Department } \\
\text { Wildlife and G } \\
\text { Sciences, Facu } \\
\text { and Agricultur } \\
\text { University of t } \\
\text { Bloemfontein, }\end{array}$ & $\begin{array}{l}\text { ff Animal, } \\
\text { rassland } \\
\text { Ity of Natural } \\
\text { al Sciences, } \\
\text { he Free State, } \\
\text { South Africa }\end{array}$ \\
\hline $\begin{array}{l}{ }^{3} \text { Department } \\
\text { Sciences, Facu } \\
\text { and Agricultur } \\
\text { University of } \mathrm{t} \\
\text { Bloemfontein, }\end{array}$ & $\begin{array}{l}\text { f Plant } \\
\text { Ity of Natural } \\
\text { al Sciences, } \\
\text { he Free State, } \\
\text { South Africa }\end{array}$ \\
\hline $\begin{array}{l}\text { Correspondin } \\
\text { Wijnand Swar } \\
\text { swartwj@ufs. }\end{array}$ & $\begin{array}{l}\text { g author: } \\
\text { t, } \\
\text { ac.za }\end{array}$ \\
\hline $\begin{array}{l}\text { Dates: } \\
\text { Received: } 26 \mathrm{~S} \\
\text { Accepted: } 04 \mathrm{~S} \\
\text { Published: } 29\end{array}$ & $\begin{array}{l}\text { ept. } 2019 \\
\text { Sept. } 2020 \\
\text { Oct. } 2020\end{array}$ \\
\hline $\begin{array}{l}\text { How to cite th } \\
\text { Vermeulen, M } \\
\text { Swart, W.J., } 20 \\
\text { rhizobiome of } \\
\text { plants in Clove } \\
\text { Sterkspruit soi } \\
\text { Stevenson-Ha } \\
\text { supersite', Koe } \\
\text { a1596. https:/ } \\
\text { org/10.4102/k } \\
\text { v62i2.1596 }\end{array}$ & $\begin{array}{l}\text { is article: } \\
\text {., Cason, E.D. \& } \\
20, \text { 'The } \\
\text { herbaceous } \\
\text { lly and } \\
\text { Is of the } \\
\text { milton } \\
\text { doe } 62(2) \text {, } \\
\text { /doi. } \\
\text { oedoe. }\end{array}$ \\
\hline $\begin{array}{l}\text { Copyright: } \\
\text { (C) 2020. The A } \\
\text { Licensee: AOS } \\
\text { is licensed unc } \\
\text { Creative Comn } \\
\text { Attribution Lic }\end{array}$ & $\begin{array}{l}\text { uthors. } \\
\text { IS. This work } \\
\text { ler the } \\
\text { nons } \\
\text { ense. }\end{array}$ \\
\hline Read online: & \\
\hline 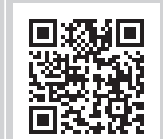 & $\begin{array}{l}\text { Scan this QR } \\
\text { code with your } \\
\text { smart phone or } \\
\text { mobile device } \\
\text { to read online. }\end{array}$ \\
\hline
\end{tabular}

By attracting microorganisms from the surrounding soil via root exudates, the composition of microbial populations in the rhizosphere of plants is regulated and maintained according to the genotype of the plant and its abiotic soil environment. This project investigated the bacterial diversity of the rhizosphere microbiome (i.e. rhizobiome) of the three most common herbaceous plants (Kyphocarpa angustifolia [Amaranthaceae, Caryophyllales], Melhania acuminata [Malvaceae, Malvales] and Sida cordifolia [Malvacae, Malvales]) growing mutually in two different soil types (Clovelly [top] and Sterkspruit [bottom]) with differing abiotic characteristics at a granite catenal supersite in the Kruger National Park, South Africa. Two plant species (K. angustifolia and S. cordifolia) occurred at both the top and bottom sites, whilst M. acuminata only occurred at the top site. Ten rhizosphere samples were collected per plant from both the top and bottom sites, comprising a total of 50 samples. Biolog EcoPlates ${ }^{\mathrm{TM}}$ were used to assess differences in carbon source utilisation patterns by bacteria in the rhizobiome. For nextgeneration sequencing analysis, the DNA from four randomly selected rhizosphere soil samples from each plant species, at both the top and bottom sites, was combined to yield two samples from each locality for each species. Targeted metagenomic sequencing of the $16 \mathrm{~S}$ rRNA gene region (V3 and V4 regions) was used to characterise the rhizobiome. Actinobacteria and Proteobacteria were the most dominant phyla in all rhizobiomes, and unique and shared operational taxonomic units were identified in all the rhizobiomes. Principal component analysis of the Biolog data revealed no disparity between the five rhizobiomes.

Conservation implications: The results obtained in this study could play a role in microecological scale conservation and management because microbial diversity in soils plays a vital role in shaping above-ground biodiversity and terrestrial ecosystem dynamics.

Keywords: Kruger National Park; Microbiome; Rhizobiome; 16S diversity; StevensonHamilton Supersite; Granite catena.

\section{Introduction}

The rhizosphere is characterised by high microbial activity and an array of complex and dynamic physical, chemical and biological interactions termed the 'rhizosphere effect' (Helliwell et al. 2019; Hiltner 1904). These interactions play a crucial role in plant nutrition (Raaijmakers et al. 2009; Sørensen 1997) and ecosystem functioning in terrestrial ecosystems (Singh et al. 2004). Microbes associated with the rhizosphere (i.e. the rhizosphere microbiome or rhizobiome) represent a vast reservoir of microbial diversity that includes fungi, bacteria, nematodes, protozoa, algae, viruses and arthropods (Berg \& Smalla 2009; Bonkowski et al. 2000; Bonkowski, Villenave \& Griffiths 2009; Bulgarelli et al. 2013). Plant species actively determine the composition of their rhizobiome by secreting root exudates that attract or repel specific bacteria from the surrounding bulk soil (Berg \& Smalla 2009; Doornbos, Van Loon \& Bakker 2012). The composition of the rhizobiome is thus determined by numerous edaphic variables of the immediately surrounding bulk soil such as the soil mineralogy, soil moisture content and $\mathrm{pH}$ (Bardgett et al. 2005; Fierer \& Jackson 2006; Myers et al. 2001). However, comparative studies on the effect of specific edaphic variables on the composition of the rhizobiome are rare because of a lack of suitable study sites where the influence of different soil types on the same plant species in close proximity can be compared effectively.

The Kruger National Park (KNP), located in the north-eastern part of South Africa, is one of the largest natural reserves in Africa, with vast areas that are mostly pristine (Carruthers 2017). This area is mostly subtropical, with deciduous savanna landscapes inhabited by diverse herbivore

Note: Special Issue: Connections between abiotic and biotic components of a granite catena ecosystem in Kruger National Park, subedited by Beanelri Janecke and Johan van Tol. 
and carnivore populations, leading to the integrity of most ecosystems within the park (Rughöft et al. 2016). To study these pristine areas, four 'research supersites' were chosen (Figure 1), each representing unique ecological, geological and climatic features within the park (Smit et al. 2013), making these sites ideal to study microbial diversity.

The Stevenson-Hamilton supersite (S-Hs) in the KNP is a granite catena (a hydrologically linked hill slope with dynamic solute, particle and colloid transport systems along the slope) (Rughöft et al. 2016) located $7 \mathrm{~km}$ south of Skukuza (Smit et al. 2013). The granite catena of the S-Hs is characterised by pronounced differences in soil differentiation along the slope of the catena with sandy soils in the upper region, clay accumulation along the slope and clayey, duplex soils with sporadic sodic patches on the foot slope (Levick et al. 2010) (Figure 1). The site was shown to have a unique bacterial community when compared to other soil ecosystems (Rughöft et al. 2016), and therefore it is ideal in terms of conducting a comparative study of the diversity of the rhizobiome of the same plant species growing in differing soil types. In most soil ecosystems, Acidobacteria and (Alpha-)Proteobacteria are the two dominant phyla, usually accompanied by Actinobacteria as another abundant group (Janssen 2006; Lauber et al. 2009; Nacke et al. 2011; Prober et al. 2015; Rughöft et al. 2016). However, the most abundant phyla in the granite soils from the S-Hs were Actinobacteria, Chloroflexi and Firmicutes (Rughöft et al. 2016). Acidobacteria, Planctomycetes, Alphaproteobacteria and Deltaproteobacteria were the phyla that most frequently occurred at a lower relative abundance (Rughöft et al. 2016).

The first objective of the present study was to assess the structural and functional diversity of bacteria in the respective rhizobiomes of the three most prevalent herbaceous plant species growing in the S-Hs in sandy soil at the top (Clovelly) and clay soil at the bottom (Sterkspruit) of the slope. A second objective was to determine whether the structural diversity of bacteria in each plant species was influenced by the surrounding bulk soil - such as the sandy soil at the top and clay soil at the bottom of the slope. A third objective was to determine the most dominant bacterial phyla in the two respective sites and to compare this with the findings of Rughöft et al. (2016). This is the first study to investigate the diversity of the bacterial rhizobiome of Kyphocarpa angustifolia (Amaranthaceae, Caryophyllales), Melhania acuminata (Malvaceae, Malvales) and Sida cordifolia (Malvaceae, Malvales) as well as to ascertain how different soil types affect microbial diversity.

\section{Materials and methods Sampling site and procedure}

Previous work done in the S-Hs has shown that the granitic catena differs in physiochemical properties from the top of the slope to the bottom (Figure 1) (Sandoval-Denis, Swart \& Crous 2018). The soil at the top of the slope is a Clovelly soil type characterised by a high percentage of sand $(90 \%)$, a lower

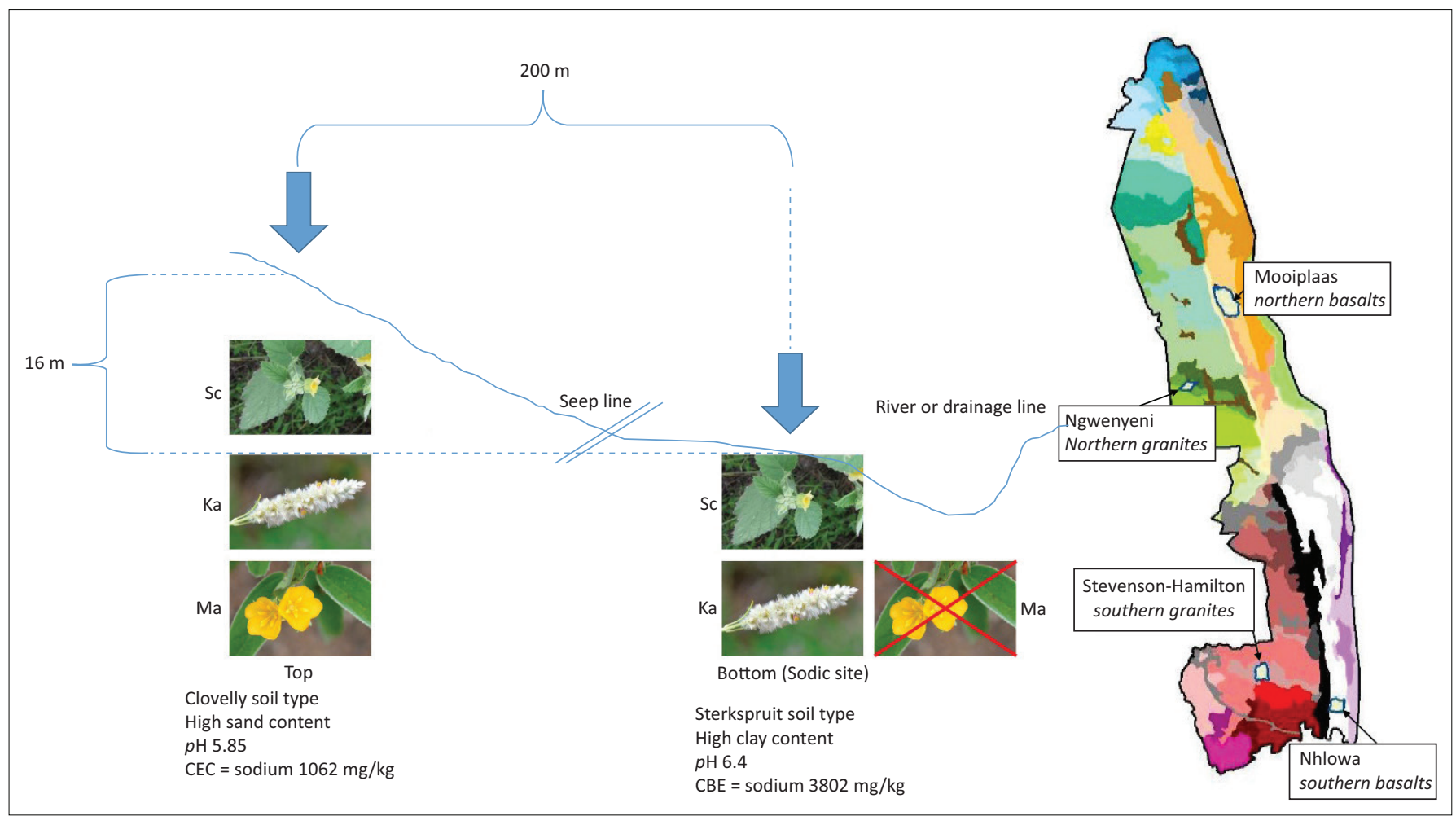

Source: Adapted from Smit, I.P.J., Riddell, E.S., Cullum, C. \& Petersen, R., 2013, 'Kruger National Park research supersites: Establishing long-term research sites for cross-disciplinary, multiscaled learning', Koedoe 55(1), 1107. https://doi.org/10.4102/koedoe.v55i1.1107 \& Janecke, B.B., Van Tol, J., Smit, I.P.J., Van Aardt, A.C., Riddell, E.S., Seaman, M.T. et al., 2020, 'Biotic and abiotic connections on a granitic catena: Framework for multidisciplinary research', Koedoe 62(2), a1600. https://doi.org/10.4102/koedoe.v62i2.1600

Note: A soil catena consisting of a hill slope (not steep, with a drop of $16 \mathrm{~m}$ over a $500 \mathrm{~m}$ length), sodic site (high sodium content), riparian and floodplain area, and the dry drainage line of the Sabie River, showing sampling sites.

Ka, Kyphocarpa angustifolia; Ma, Melhania acuminate; Sc, Sida cordifolia; CEC, cation exchange capacity.

FIGURE 1: Kruger National Park supersites and the Stevenson-Hamilton granite supersite catena. 
cation exchange capacity (CEC) (mean sodium concentration of $1062 \mathrm{mg} / \mathrm{kg}$ ) and low $\mathrm{pH}$ (mean 5.85) (Sandoval-Denis et al. 2018). The bottom of the slope is characterised by a Sterkspruit soil type, with a higher clay content, leading to a higher CEC (mean sodium concentration of $3802 \mathrm{mg} / \mathrm{kg}$ ) and higher $\mathrm{pH}$ (mean 6.4) (Bouwer, Le Roux \& Van Tol 2020; Janecke et al. 2020; Sandoval-Denis et al. 2018).

Three species of plants, K. angustifolia, M. acuminata and S. cordifolia, were identified as the most prominent plant species in the catena as per recommendation by a local botanist (J. Du Preez, pers. comm.). Kyphocarpa angustifolia and M. acuminata are not endemic to South Africa, whilst S. cordifolia is an invasive plant species that could have major effects on the microbial communities in soil (Van Der Putten, Klironomos \& Wardle 2007). Two species (K. angustifolia and S. cordifolia) occurred at both the top and bottom of the slope, whilst M. acuminata only occurred at the top site (Figure 1). All soil samples were collected on 15 March 2015, during a period with very frequent rain occurring in the area.

The rhizosphere soil of 10 plants of the same species occurring at each top or bottom site was sampled using a core soil sampler. A Global Positioning System (GPS) waypoint reading was recorded for each plant sampled (Table 1). Because sampling was initiated on three species at the top of the slope and M. acuminata was not found at the bottom of the slope, a total of 50 soil samples were taken. Approximately $200 \mathrm{~g}$ of soil from each plant was sampled and placed in a zip-lock plastic bag and kept on ice in an insulated container at approximately $5{ }^{\circ} \mathrm{C}$ until analysed in the laboratory. Rhizosphere soil samples destined for rhizobiome analysis were stored at $-80{ }^{\circ} \mathrm{C}$.

\section{Community-level physiological profiles}

Biolog EcoPlates ${ }^{\mathrm{TM}}$ investigate the functional diversity or metabolic potential of that part of a bacterial community that is capable of being metabolically active under axenic conditions. A soil suspension was made for the 50 rhizosphere soil samples by suspending $2 \mathrm{~g}$ of each soil sample (Table 1) in $200 \mathrm{~mL}$ of sterilised water. To totally suspend the soil in water, the samples were shaken for $30 \mathrm{~min}$ at room temperature. Each well of the microtitre plate was then filled with $90 \mu \mathrm{L}$ of the soil suspension, and the plates were incubated at $25{ }^{\circ} \mathrm{C}$ in a Labcon growth chamber in the dark for $96 \mathrm{~h}$ (4 days).

The change in optical density (OD) was then measured using a multiwell plate reader at $590 \mathrm{~nm}$. The overall colour development in each Biolog EcoPlate ${ }^{\mathrm{TM}}$ was expressed as average well colour development (AWCD) (Zak et al. 1994). Data were statistically analysed with XLSTAT by conducting an analysis of variance (single factor), and then means separation was performed using Fischer's least significant difference (LSD) $(p \leq 0.05)$. Two methods of multivariate analysis were applied to the results: cluster analysis and principal component analysis (PCA).

\section{Rhizosphere microbiome characterisation: DNA extraction, bacterial $16 \mathrm{~S}$ amplicon preparation and Illumina MiSeq sequencing}

Because of cost implications, only four rhizosphere soil samples were chosen randomly from each plant species at both the top and bottom sites, to yield a total of 20 samples (Table 1). DNA was extracted from soil samples using a NucleoSpin ${ }^{\circledR}$ soil kit with some modifications from the manufacturer's instructions. Ceramic beads from the NucleoSpin ${ }^{\circledR}$ bead type A were transferred to a 2-mL clip cap Eppendorf tube, and sample lysis was done in a tissue lyser, whereafter the instructions of the manufacturer were followed. Ten composite DNA samples were then prepared by combining two samples from each locality for each plant species. DNA concentrations were determined on a NanoDrop 2000 and standardised to $10 \mathrm{ng} / \mu \mathrm{L}$ in $5 \mathrm{mM}$ Tris buffer ( $\mathrm{pH} 8.5)$.

A portion of the $16 \mathrm{~S}$ rRNA gene region (V3 and V4 regions) was amplified for each DNA sample following a modified version of the Illumina MiSeq 16S metagenomics sequencing library preparation guide (http://support.illumina.com). Reactions were performed, in duplicate, in a total volume of $25 \mu \mathrm{L}$, consisting of $25 \mathrm{ng}$ DNA template, $1.5 \mu \mathrm{L}(0.3 \mu \mathrm{M})$ of each primer, $12.5 \mu \mathrm{L}$ KAPA HiFi HotStart ready mix $(1 \times)$ and $7 \mu \mathrm{L}$ nuclease free water. The polymerase chain reaction (PCR) program included an initial denaturation step of $95^{\circ} \mathrm{C}$ for $3 \mathrm{~min}$ followed by 25 amplification cycles consisting of $98^{\circ} \mathrm{C}$ for $30 \mathrm{~s}, 65^{\circ} \mathrm{C}$ for $30 \mathrm{~s}$ and $72{ }^{\circ} \mathrm{C}$ for $30 \mathrm{~s}$, followed by a final extension step at $72{ }^{\circ} \mathrm{C}$ for $5 \mathrm{~min}$. Polymerase chain reaction products were viewed with UV light on $2 \%$ agarose gels with GelRed ${ }^{\mathrm{TM}}$. The PCR products of each soil sample were combined for downstream analyses at the Next Generation Sequencing Facility at the University of the Free State, following the Illumina MiSeq $16 S$ metagenomics sequencing library preparation guide for the $2 \times 300 \mathrm{bp}$ MiSeq v3 kit (http:/ / support.illumina.com).

The quality of sequences was assessed using FastQC (Andrews 2010), and the sequences were filtered and trimmed using PrinSeq-lite v0.20.4 (Schmieder \& Edwards 2011) to have a mean quality score (QC) of $>20$ and a sequence length of $>200 \mathrm{bp}$. Paired-end reads were merged using Paired-End reAd mergeR (PEAR) v0.9.6 (Zhang et al. 2014). Chimeric sequences were identified using usearch v6.1.544 (Edgar 2010) against the ribosomal database project (RDP) 'Gold' database (Edgar 2010). The quantitative insight into microbial ecology (QIIME) v1.9.1 framework was used for subsequent sequence data analyses (Caporaso et al. 2010; Lozupone et al. 2010). A closed-reference operational taxonomic unit (OTU) picking workflow was followed, and OTUs were picked against the Silva database v132 at 97\% sequence identity. Operational taxonomic unit tables were normalised, and all analyses were carried out using $\mathrm{R}$ (www.r-project.org).

Operational taxonomic unit richness and phylogenetic diversity (PD) were calculated using phyloseq (McMurdie \& Holmes 
TABLE 1: Plant species and Global Positioning System location on granite catena for rhizosphere soil samples analysed by means of Biolog EcoPlates ${ }^{\text {TM }}$ and $16 \mathrm{~S}$ microbial diversity.

\begin{tabular}{|c|c|c|c|c|c|c|c|}
\hline Plant species & Location & Waypoint number & Waypoint S & Waypoint E & $\begin{array}{l}\text { Sample used for } \\
\text { DNA extraction }\end{array}$ & $\begin{array}{l}\text { Sample ID for } \\
\text { 16s biodiversity }\end{array}$ & $\begin{array}{c}\text { Biolog } \\
\text { EcoPlates }\end{array}$ \\
\hline \multirow{10}{*}{$\begin{array}{l}\text { Melhania } \\
\text { acuminata }\end{array}$} & TOP & $\# 001$ & $S 25^{\circ} 06^{\prime} 50.9^{\prime \prime}$ & E $031^{\circ} 34^{\prime} 37.6^{\prime \prime}$ & - & - & AT\#1 \\
\hline & TOP & $\# 002$ & S $25^{\circ} 06^{\prime} 51.3^{\prime \prime}$ & E $031^{\circ} 34^{\prime} 37.6^{\prime \prime}$ & $65-A 002$ & MaT-2/4 & AT\#2 \\
\hline & TOP & $\# 003$ & $S 25^{\circ} 06^{\prime} 51.6^{\prime \prime}$ & E $031^{\circ} 34^{\prime} 37.4^{\prime \prime}$ & - & - & AT\#3 \\
\hline & TOP & $\# 004$ & S $25^{\circ} 06^{\prime} 51.3^{\prime \prime}$ & E $031^{\circ} 34^{\prime} 37.0^{\prime \prime}$ & 66-A004 & - & AT\#4 \\
\hline & TOP & $\# 005$ & $S 25^{\circ} 06^{\prime} 51.4^{\prime \prime}$ & E $031^{\circ} 34^{\prime} 37.4^{\prime \prime}$ & - & - & AT\#5 \\
\hline & TOP & $\# 014$ & $S 25^{\circ} 06^{\prime} 48.6^{\prime \prime}$ & $\mathrm{E} 031^{\circ} 34^{\prime} 36.5^{\prime \prime}$ & 67-A014 & MaT-14/20 & AT\#6 \\
\hline & TOP & $\# 019$ & $S 25^{\circ} 06^{\prime} 45.7^{\prime \prime}$ & $\mathrm{E} 031^{\circ} 34^{\prime} 35.4^{\prime \prime}$ & - & - & AT\#7 \\
\hline & TOP & $\# 020$ & $S 25^{\circ} 06^{\prime} 45.6^{\prime \prime}$ & E $031^{\circ} 34^{\prime} 37.7^{\prime \prime}$ & $68-\mathrm{A} 020$ & - & AT\#8 \\
\hline & TOP & \#024 & $S 25^{\circ} 06^{\prime} 45.9^{\prime \prime}$ & E $031^{\circ} 34^{\prime} 35.0^{\prime \prime}$ & - & - & AT\#9 \\
\hline & TOP & $\# 027$ & $S 25^{\circ} 06^{\prime} 45.8^{\prime \prime}$ & E $031^{\circ} 34^{\prime} 34.9^{\prime \prime}$ & - & - & AT\#10 \\
\hline \multirow{20}{*}{$\begin{array}{l}\text { Kyphocarpa } \\
\text { angustifolia }\end{array}$} & TOP & $\# 008$ & S $25^{\circ} 06^{\prime} 51.4^{\prime \prime}$ & E $031^{\circ} 34^{\prime} 37.5^{\prime \prime}$ & 69-B008 & КаТ8/9 & BT\#1 \\
\hline & TOP & $\# 009$ & $\mathrm{~S} 25^{\circ} 06^{\prime} 51.8^{\prime \prime}$ & $\mathrm{E} 031^{\circ} 34^{\prime} 38.1^{\prime \prime}$ & 70-B009 & - & BT\#2 \\
\hline & TOP & $\# 010$ & $S 25^{\circ} 06^{\prime} 48.2^{\prime \prime}$ & E $031^{\circ} 34^{\prime} 37.4^{\prime \prime}$ & - & - & BT\#3 \\
\hline & TOP & $\# 013$ & $S 25^{\circ} 06^{\prime} 48.4^{\prime \prime}$ & $\mathrm{E} 031^{\circ} 34^{\prime} 36.8^{\prime \prime}$ & 71-B013 & КаТ-13/23 & BT\#4 \\
\hline & TOP & $\# 016$ & $\mathrm{~S} 25^{\circ} 06^{\prime} 48.9^{\prime \prime}$ & E $031^{\circ} 34^{\prime} 36.6^{\prime \prime}$ & - & - & BT\#5 \\
\hline & TOP & $\# 017$ & $\mathrm{~S} 25^{\circ} 06^{\prime} 45.6^{\prime \prime}$ & $\mathrm{E} 031^{\circ} 34^{\prime} 35.4^{\prime \prime}$ & - & - & BT\#6 \\
\hline & TOP & $\# 018$ & $S 25^{\circ} 06^{\prime} 45.7^{\prime \prime}$ & $\mathrm{E} 031^{\circ} 34^{\prime} 35.3^{\prime \prime}$ & - & - & BT\#7 \\
\hline & TOP & $\# 023$ & $S 25^{\circ} 06^{\prime} 45.9^{\prime \prime}$ & E $031^{\circ} 34^{\prime} 35.0^{\prime \prime}$ & 72-B023 & - & BT\#8 \\
\hline & TOP & $\# 025$ & $S 25^{\circ} 06^{\prime} 45.8^{\prime \prime}$ & $\mathrm{E} 031^{\circ} 34^{\prime} 34.9^{\prime \prime}$ & - & - & BT\#9 \\
\hline & TOP & $\# 026$ & $S 25^{\circ} 06^{\prime} 45.8^{\prime \prime}$ & E $031^{\circ} 34^{\prime} 34.9^{\prime \prime}$ & - & - & BT\#10 \\
\hline & воттом & \#031 & $S 25^{\circ} 06^{\prime} 33.8^{\prime \prime}$ & $\mathrm{E} 031^{\circ} 34^{\prime} 41.1^{\prime \prime}$ & - & - & BB\#1 \\
\hline & воттом & \#032 & $S 25^{\circ} 06^{\prime} 33.8^{\prime \prime}$ & $\mathrm{E} 031^{\circ} 34^{\prime} 41.1^{\prime \prime}$ & - & - & BB\#2 \\
\hline & воттом & \#033 & $S 25^{\circ} 06^{\prime} 34.0^{\prime \prime}$ & $\mathrm{E} 031^{\circ} 34^{\prime} 40.5^{\prime \prime}$ & - & - & BB\#3 \\
\hline & воттом & \#034 & S $25^{\circ} 06^{\prime} 34.4^{\prime \prime}$ & $\mathrm{E} 031^{\circ} 34^{\prime} 40.5^{\prime \prime}$ & 73-B034 & КаВ-34/39 & BB\#4 \\
\hline & воттОМ & \#039 & S $25^{\circ} 06^{\prime} 33.9^{\prime \prime}$ & E $031^{\circ} 34^{\prime} 40.9^{\prime \prime}$ & 74-В039 & - & BB\#5 \\
\hline & воттом & $\# 043$ & S $25^{\circ} 06^{\prime} 33.3^{\prime \prime}$ & $\mathrm{E} 031^{\circ} 34^{\prime} 42.3^{\prime \prime}$ & - & - & BB\#6 \\
\hline & воттОМ & $\# 044$ & $\mathrm{~S} 25^{\circ} 06^{\prime} 33.2^{\prime \prime}$ & $\mathrm{E} 031^{\circ} 34^{\prime} 42.3^{\prime \prime}$ & - & - & BB\#7 \\
\hline & BOTTOM & $\# 045$ & S $25^{\circ} 06^{\prime} 33.4^{\prime \prime}$ & E $031^{\circ} 34^{\prime} 42.3^{\prime \prime}$ & 75-B045 & КаВ-45/47 & BB\#8 \\
\hline & вотTOM & \#046 & S $25^{\circ} 06^{\prime} 33.4^{\prime \prime}$ & $\mathrm{E} 031^{\circ} 34^{\prime} 42.3^{\prime \prime}$ & - & - & BB\#9 \\
\hline & воттом & $\# 047$ & $S 25^{\circ} 06^{\prime} 33.4^{\prime \prime}$ & $\mathrm{E} 031^{\circ} 34^{\prime} 42.4^{\prime \prime}$ & 76-B047 & - & $\mathrm{BB} \# 10$ \\
\hline \multirow[t]{20}{*}{ Sida cordifolia } & TOP & $\# 006$ & S $25^{\circ} 06^{\prime} 51.3^{\prime \prime}$ & E $031^{\circ} 34^{\prime} 37.5^{\prime \prime}$ & - & - & CT\#1 \\
\hline & TOP & $\# 007$ & $\mathrm{~S} 25^{\circ} 06^{\prime} 51.5^{\prime \prime}$ & $\mathrm{E} 031^{\circ} 34^{\prime} 37.6^{\prime \prime}$ & - & - & CT\#2 \\
\hline & TOP & \#011 & $\mathrm{S} 25^{\circ} 06^{\prime} 48.3^{\prime \prime}$ & E $031^{\circ} 34^{\prime} 37.5^{\prime \prime}$ & 77-C011 & ScT-11/15 & СТ\#3 \\
\hline & TOP & $\# 012$ & S $25^{\circ} 06^{\prime} 49.0^{\prime \prime}$ & E $031^{\circ} 34^{\prime} 37.3^{\prime \prime}$ & - & - & $\mathrm{CT} \# 4$ \\
\hline & TOP & \#015 & $S 25^{\circ} 06^{\prime} 48.8^{\prime \prime}$ & $\mathrm{E} 031^{\circ} 34^{\prime} 36.6^{\prime \prime}$ & 78-C015 & - & CT\#5 \\
\hline & TOP & $\# 021$ & $S 25^{\circ} 06^{\prime} 45.6^{\prime \prime}$ & $\mathrm{E} 031^{\circ} 34^{\prime} 35.8^{\prime \prime}$ & - & - & CT\#6 \\
\hline & TOP & $\# 022$ & S $25^{\circ} 06^{\prime} 45.8^{\prime \prime}$ & E $031^{\circ} 34^{\prime} 35.3^{\prime \prime}$ & - & - & СТ\#7 \\
\hline & TOP & $\# 028$ & $S 25^{\circ} 06^{\prime} 45.7^{\prime \prime}$ & $\mathrm{E} 031^{\circ} 34^{\prime} 35.1^{\prime \prime}$ & 79-C028 & ScT-28/30 & СТ\#8 \\
\hline & TOP & $\# 029$ & $S 25^{\circ} 06^{\prime} 45.7^{\prime \prime}$ & $\mathrm{E} 031^{\circ} 34^{\prime} 35.0^{\prime \prime}$ & - & - & СТ\#9 \\
\hline & TOP & \#030 & S $25^{\circ} 06^{\prime} 45.5^{\prime \prime}$ & $\mathrm{E} 031^{\circ} 34^{\prime} 35.0^{\prime \prime}$ & 80-С030 & - & CT\#10 \\
\hline & воттом & \#035 & S $25^{\circ} 06^{\prime} 34.9^{\prime \prime}$ & E $031^{\circ} 34^{\prime} 40.6^{\prime \prime}$ & 81-С035 & ScB-35/38 & CB\#1 \\
\hline & вотTOM & \#036 & S $25^{\circ} 06^{\prime} 35.0^{\prime \prime}$ & $\mathrm{E} 031^{\circ} 34^{\prime} 41.2^{\prime \prime}$ & - & - & $\mathrm{CB} \# 2$ \\
\hline & воттОМ & \#037 & S $25^{\circ} 06^{\prime} 34.9^{\prime \prime}$ & $\mathrm{E} 031^{\circ} 34^{\prime} 40.8^{\prime \prime}$ & - & - & CB\#3 \\
\hline & воттОМ & \#038 & $\mathrm{S} 25^{\circ} 06^{\prime} 35.0^{\prime \prime}$ & $\mathrm{E} 031^{\circ} 34^{\prime} 41.2^{\prime \prime}$ & 82-C038 & - & CB\#4 \\
\hline & воттОМ & $\# 040$ & $\mathrm{~S} 25^{\circ} 06^{\prime} 33.0^{\prime \prime}$ & $\mathrm{E} 031^{\circ} 34^{\prime} 41.4^{\prime \prime}$ & - & - & CB\#5 \\
\hline & вотTOM & $\# 041$ & S $25^{\circ} 06^{\prime} 32.9^{\prime \prime}$ & $\mathrm{E} 031^{\circ} 34^{\prime} 41.5^{\prime \prime}$ & - & - & CB\#6 \\
\hline & воттом & $\# 042$ & S $25^{\circ} 06^{\prime} 33.2^{\prime \prime}$ & E $031^{\circ} 34^{\prime} 41.6^{\prime \prime}$ & - & - & CB\#7 \\
\hline & воттом & $\# 048$ & $\mathrm{~S} 25^{\circ} 06^{\prime} 33.9^{\prime \prime}$ & E $031^{\circ} 34^{\prime} 41.7^{\prime \prime}$ & 83-C048 & ScB-48/49 & CB\#8 \\
\hline & воттом & $\# 049$ & $\mathrm{~S} 25^{\circ} 06^{\prime} 33.6^{\prime \prime}$ & E $031^{\circ} 34^{\prime} 42.7^{\prime \prime}$ & 84-C049 & - & CB\#9 \\
\hline & воттом & $\# 050$ & $\mathrm{~S} 25^{\circ} 06^{\prime} 34.5^{\prime \prime}$ & $\mathrm{E} 031^{\circ} 34^{\prime} 42.4^{\prime \prime}$ & - & - & $\mathrm{CB} \# 10$ \\
\hline
\end{tabular}

2013) in R (Team RDC 2011). The potential functional capacity of the OTUs was predicted using functional annotation of prokaryotic taxa (FAPROTAX) (Louca, Parfrey \& Doebeli 2016). The taxonomic and functional structures of the microbial community were visualised using principal coordinate analysis (PCoA). Permutational analysis of variance (PERMANOVA) was used to test for differences in composition and function between and within habitats, whereas permutation dispersion (PERMDISP) was used to test for differences in habitat dissimilarity; both analyses were performed with the 'adonis' and 'betadisper' functions in vegan (Oksanen et al. 2013) for R.

\section{Ethical considerations}

Ethical approval for the multidisciplinary project as a whole was obtained from the Interfaculty Animal Ethics Committee at the University of the Free State (UFS-AED2019/0121). The SANParks permit numbers for the collection of soil for 
lab analyses and vegetation for identification purposes are SK069, SK2095 and SK054.

\section{Results}

\section{Community-level physiological profiles}

Principal component analysis and AWCD data (mean of the absorbance values for a whole plate) revealed no disparity between the rhizosphere samples from $K$. angustifolia and S. cordifolia from the Sterkspruit site (bottom) and those of K. angustifolia, M. acuminata and S. cordifolia from the Clovelly site (top) (PCA data not shown). Based on the AWCD data, after $96 \mathrm{~h}$ there were also no significant differences $(p>0.05)$ between the five samples (Figure 2 ).

\section{Rhizosphere microbiome characterisation: DNA extraction, bacterial $16 \mathrm{~S}$ amplicon preparation and Illumina MiSeq sequencing}

A total of 171091 sequences were obtained from the 16S library after quality assessment and data filtering ranging from $62246(\max )$ sequences to 5955 ( $\mathrm{min}$ ) sequences, with 6223 to 2119 OTUs ( $97 \%$ similarity cut-off). Rarefaction curves (not shown) indicated that deeper sequencing is needed to completely resolve the prokaryotic diversity of the samples. After rarefication there were 3374 sequences per sample with a total of 3952 OTUs ( $97 \%$ similarity cut-off) for all samples. Of the total number of OTUs, 581 (representing $4.78 \%$ of the total number of sequences) were unique to K. angustifolia at the Clovelly site (top), $313(2.02 \%)$ were unique to M. acuminata at the Clovelly site (top), 263 (1.72\%) were unique to S. cordifolia at the Clovelly site (top), 234 (1.80\%) were unique to K. angustifolia at the Sterkspruit site (bottom), $332(1.63 \%)$ were unique to S. cordifolia at the Sterkspruit site (bottom) and $315(47.72 \%)$ were shared between all the rhizosphere samples.

Percentage relative abundance plots (Figure 3) showed that the phyla Actinobacteria $(11.74 \%-36.22 \%)$ and Proteobacteria $(10.23 \%-30.79 \%)$ were amongst the most dominant phyla in all rhizosphere samples. In contrast, the phylum

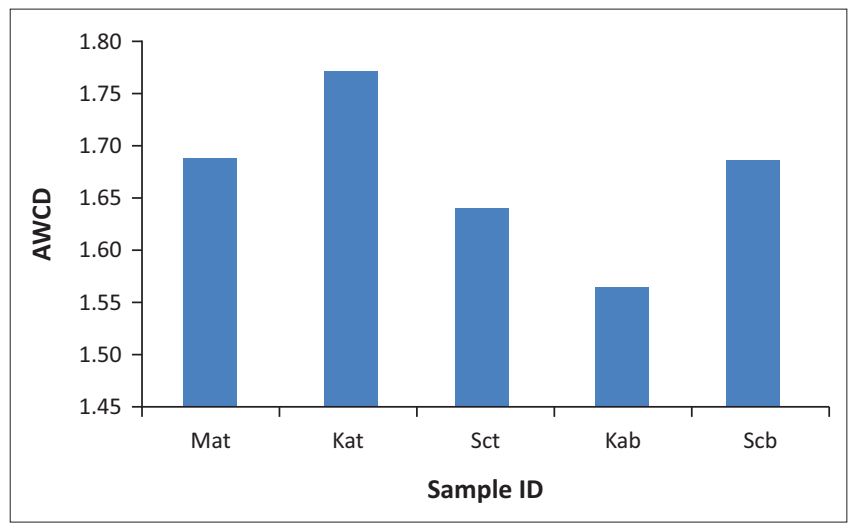

$p>0.05$ (no statistical difference).

Ka, Kyphocarpa angustifolia; ma, Melhania acuminate; sc, Sida cordifolia; b, bottom; t, top AWCD, average well colour development.

FIGURE 2: Carbon substrate utilisation activity as average well colour development by the rhizosphere microbial community.
Verrucomicrobia was one of the dominant phyla in the rhizosphere samples, from one of the K. angustifolia (22.67\%) samples from the Sterkspruit site (bottom) and both the samples from K. angustifolia (19.71\%, 18.94\%), M. acuminata $(42.77 \%, 26.08 \%)$ to S. cordifolia $(29.31 \%, 25.49 \%)$ from the Clovelly site (top). Planctomycetes was one of the dominant phyla in the second K. angustifolia (47.69\%) rhizosphere samples from the Sterkspruit site (bottom) and Firmicutes $(19.85 \%)$ and Chloroflexi (17.13\%), respectively, in the S. cordifolia rhizosphere samples from the Sterkspruit site (bottom) (Figure 3).

Distinct prokaryotic communities (OTU level) were not observed between the five rhizosphere samples, K. angustifolia and S. cordifolia from the Sterkspruit site (bottom) to K. angustifolia, M. acuminata and S. cordifolia from the Clovelly site (top) (PERMANOVA $F_{4.9}=0.96, R^{2}=43 \%, p>0.1$ ). However, the PCoA showed that samples from the Clovelly site (top) clustered together (Figure 4). The functional capacity of the OTUs (Figure 5) showed a distinct association between the five rhizosphere samples, K. angustifolia and S. cordifolia from the Sterkspruit site (bottom) and K. angustifolia, M. acuminata and S. cordifolia from the Clovelly site (top) (PERMANOVA $F_{1.9}=1.72, R^{2}=18 \%, p \leq 0.1$ ). Samples from the Clovelly (top) site clustered together (Figure 6). Overall, the rhizosphere communities were dominated by chemoheterotrophy $(20.05 \%-32.25 \%)$ and aerobic chemoheterotrophy $(16.35 \%-30.34 \%)$ (Figure 5). Although present at low percentages of the total rhizosphere community, sulphur respiration $(0.01 \%-0.18 \%)$, iron respiration $(0.05 \%-0.12 \%)$, sulphite respiration $(0.01 \%-$ $0.12 \%)$ and thiosulphate respiration $(0.01 \%-0.12 \%)$ were only present at the Sterkspruit site (bottom) for both K. angustifolia and S. cordifolia (Figure 5). In contrast, arsenate respiration $(0.02 \%-0.06 \%)$, dissimilatory arsenate reduction $(0.02 \%-0.06 \%)$, nitrate ammonification $(0.02 \%-0.06 \%)$ and nitrite ammonification $(0.02 \%-0.06 \%)$ were only present in K. angustifolia at the Sterkspruit site (bottom) and dark hydrogen oxidation $(0.05 \%-0.08 \%)$ and reductive acetogenesis $(0.05 \%-0.08 \%)$ only in S. cordifolia at the Sterkspruit site (bottom) (Figure 5).

\section{Discussion}

The rhizobiome is shaped by complex interactions between the soil type, plant species and root zone location (Marschner et al. 2001). Although there were no statistically significant differences between the rhizobiome of the Clovelly (top) and Sterkspruit (bottom) soil types or between the three different plant species, it was evident that the soil type and plant species did have a role in shaping the rhizobiome, as unique OTUs were observed in all five different rhizosphere samples. This has previously been observed, with soil type (Bachman \& Kinzel 1992) and plant species (Wieland, Neumann \& Backhaus 2001) both being reported as the driving factor for microbial soil and rhizosphere diversity. Although the sampling area spanned only $200 \mathrm{~m}$, differences in plant diversity were observed in previous studies of the plant diversity of the S-Hs 


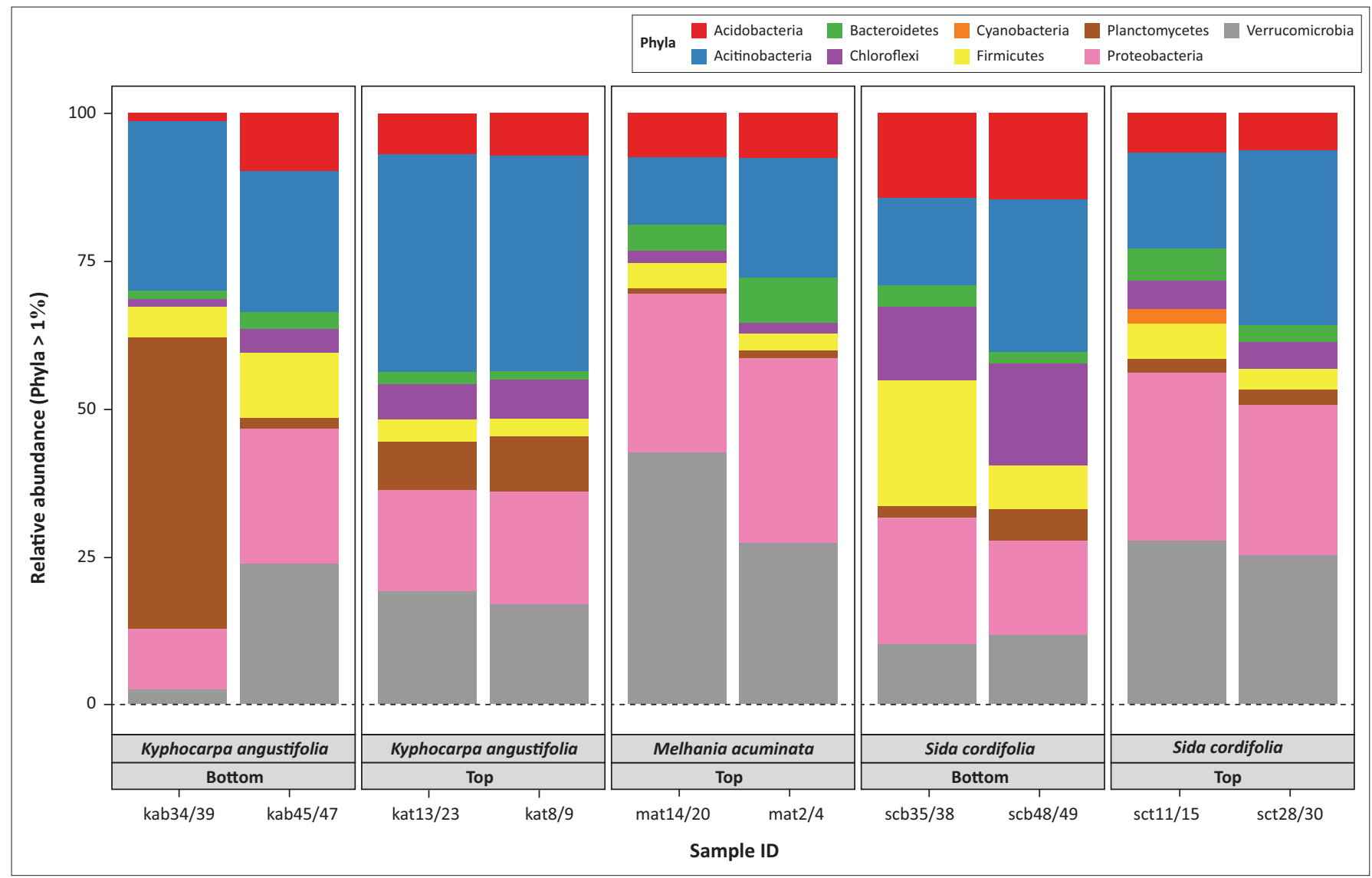

Note: The graph represents the percentage relative abundance at phylum level.

Ka, Kyphocarpa angustifolia; ma, Melhania acuminata; sc, Sida cordifolia; b, bottom; t, top.

FIGURE 3: Taxonomic identification.

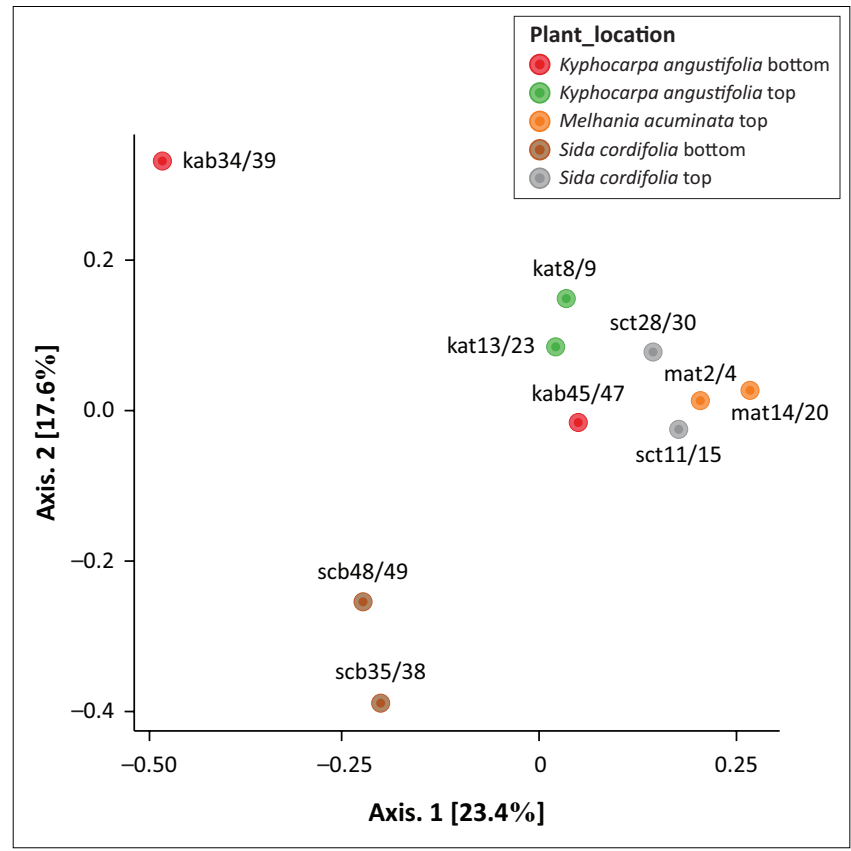

Ka, Kyphocarpa angustifolia; ma, Melhania acuminata; sc, Sida cordifolia; b, bottom; t, top. FIGURE 4: Principal coordinates analysis of the rhizosphere microbiome for Kyphocarpa angustifolia and Sida cordifolia from the Sterkspruit site (bottom) and $K$. angustifolia, Melhania acuminata and S. cordifolia from the Clovelly site (top).

granite catena (Theron, Van Aardt \& Du Preez 2020). This was also reflected in the bulk soil microbiome diversity of the S-Hs granite catena (Rughöft et al. 2016) along the slope and is thus expected for the rhizobiome of the resident plants. There was, however, a significant amount of shared OTUs (47.72\% of the total number of sequences) regardless of the soil type and specific plant rhizosphere they occurred in.

The invasive plant, S. cordifolia, is known to have antimicrobial properties (Pallela et al. 2018; Thangavel, Raveendran \& Kathirvel 2006); however, there is no information available on its rhizobiome. Similarly, now information is available for the rhizobiome of the two native plants, K. angustifolia and $M$. acuminata. The soil surrounding the rhizosphere serves as the main reservoir for the microorganisms that form part of the rhizobiome (Berg \& Smalla 2009). Actinobacteria and Proteobacteria were amongst the most dominant phyla in all rhizosphere samples, whilst Verrucomicrobia and Planctomycetes were the dominant phyla in the rhizosphere samples from K. angustifolia at the Sterkspruit site (bottom), Verrucomicrobia in $K$. angustifolia, M. acuminata and S. cordifolia at the Clovelly site (top) and Firmicutes and Chloroflexi in the S. cordifolia rhizosphere samples from the Sterkspruit site (bottom) (Figure 3). Previous studies on the soil in the KNP S-Hs showed that Actinobacteria, Chloroflexi and Firmicutes were dominant, whilst Planctomycetes, Proteobacteria and Verrucomicrobia most frequently had the lowest relative abundance (Rughöft et al. 2016). Therefore, although the abundance of specific bacterial phyla may differ 


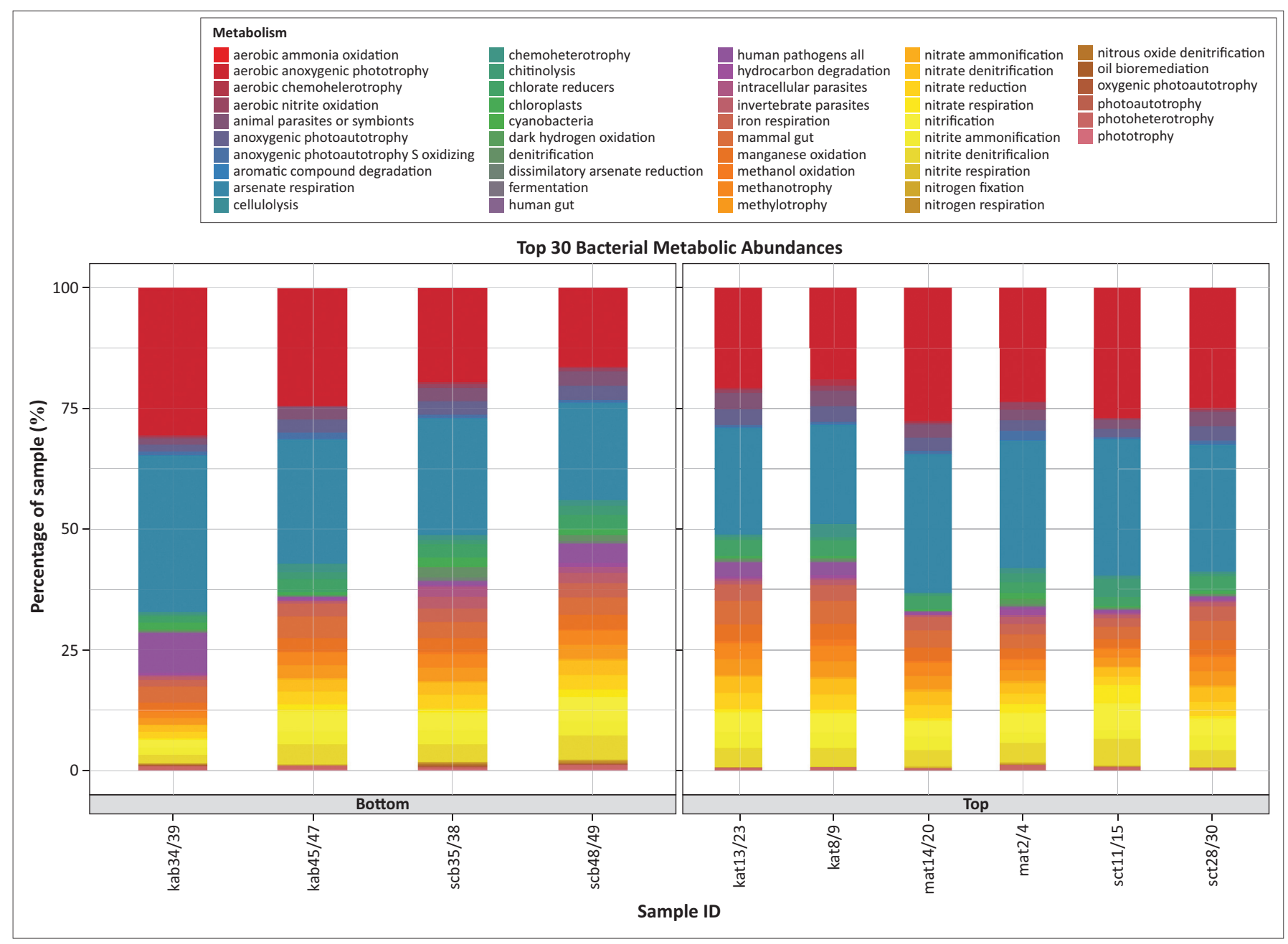

Note: Ka, Kyphocarpa angustifolia; ma, Melhania acuminata; sc, Sida cordifolia; b, bottom; t, top.

FIGURE 5: Potential functional capacity for each sample.

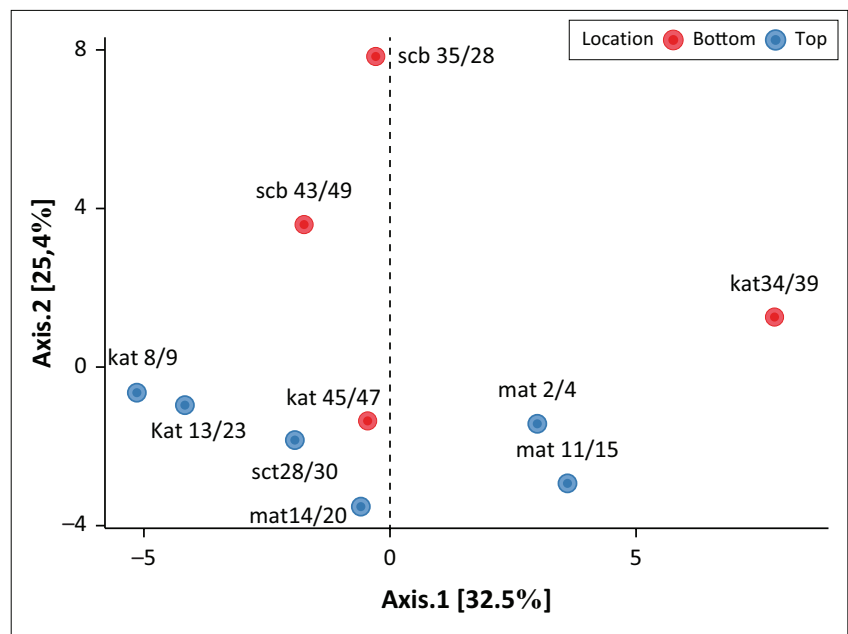

Ka, Kyphocarpa angustifolia; ma, Melhania acuminata; sc, Sida cordifolia; b, bottom; t, top. FIGURE 6: Principal coordinates analysis of the functional capacity for the rhizosphere microbiome for Kyphocarpa angustifolia and Sida cordifolia from the Sterkspruit site (bottom) and K. angustifolia, Melhania acuminata and S. cordifolia from the Clovelly site (top).

between the rhizobiome and bulk soil (Rughöft et al. 2016), our results are consistent with those of Berg and Smalla (2009), who suggested that root exudates in the rhizosphere select specific microbes from the surrounding bulk soil. To our knowledge, there are no studies comparing the bacterial rhizobiome of native and invasive plants within the study site. Gryzenhout et al. (2020), however, studied the fungal rhizobiome of the same plant species in S-Hs and found that S. cordifolia only attracted half the number of OTUs compared to the native plants, M. acuminata and K. angustifolia, which could be attributed to the antimicrobial properties of S. cordifolia. However, this was not observed for the bacterial rhizobiome.

Actinobacteria, Chloroflexi, Firmicutes and Verrucomicrobia are well adapted to survival in the nutrient- and water-poor soils of the KNP S-Hs (Rughöft et al. 2016). The increase in abundance of Proteobacteria in the rhizosphere compared to the surrounding soil could be because they have been shown to benefit from the higher nutrient levels, especially carbon availability (Leff et al. 2015; Wang, Ji \& Gao 2016), that will be expected because of root exudates in the rhizosphere (Haichar et al. 2014). Planctomycetes and Verrucomicrobia, although not dominant in all samples, were present $(>1 \%)$ in all samples and have been reported in other studies on rhizobiomes (Gkarmiri et al. 2017; Zeng et al. 2018; Zhou et al. 2019). Similar to Proteobacteria, Planctomycetes and Verrucomicrobia could benefit from the increased availability 
of nutrients in the rhizosphere. Planctomycetes are known to play a role in carbohydrate metabolism (Fuerst 1995), and a lineage in the Planctomycetes has also been shown to play a role in anaerobic oxidation of ammonium (Strous et al. 1999). Planctomycetes present in the rhizosphere and bulk soil samples from the S-Hs granite catena could therefore play a role in the oxidation of ammonium reported in this soil (Rughöft et al. 2016).

According to the bacterial functional group analyses, soil type (i.e. Clovelly vs. Sterkspruit) (Figure 6) played a role in the composition of the bacterial functional groups. These two soil types present different environments for the rhizospheres. Clovelly soils have low fertility and waterholding capacity, when compared with those of other soils of the same clay content, which would affect the rhizosphere diversity and thus functionality when compared to the Sterkspruit soil type. The Sterkspruit soil type is characterised by a higher clay content, leading to a higher CEC. The most important factors pertaining to these soils that affect the rhizosphere biome are the elevated sodium concentration in the Sterkspruit soil type $(3802 \mathrm{mg} / \mathrm{kg}$ vs. $1062 \mathrm{mg} / \mathrm{kg}$ ) and more acidic $\mathrm{pH}$ in the Clovelly soil type (5.85 vs. 6.4) (Sandoval-Denis et al. 2018; Theron et al. 2020). Higher sodium could lead to lower osmotic potential, making it more difficult for microbes and plant roots to extract water from soils (Yan et al. 2015). Differences in $\mathrm{pH}$ would also mediate nutrient availability in soils (Zhalnina et al. 2015), affecting the rhizobiome.

Chemoheterotrophy and aerobic chemoheterotrophy were the most abundant identified functions in all rhizobiomes (Figure 5). However, this is expected for bacterial communities that use organic carbon as the main food source (heterotrophic bacteria) (Zhang et al. 2019). In the absence of oxygen, a wide range of compounds can serve as terminal electron donors (anaerobic respiration). The availability of oxygen in the rhizosphere is one of the most changing factors and anaerobic/anoxic conditions may develop (Philippot et al. 2013), leading to bacteria adapting to using various anaerobic respiration strategies. This was observed with iron, sulphur, sulphite and thiosulphate respiration, present at the Sterkspruit site (bottom) in both K. angustifolia and S. cordifolia, and arsenate respiration in K. angustifolia (Figure 5). It is possible that the higher clay content of the Sterkspruit soil could also play a role, as anaerobic respiration was only observed in the rhizobiomes associated with this particular soil type.

\section{Conclusion}

Soil type (Clovelly vs. Sterkspruit) and differences in $\mathrm{pH}$ and salinity (Figure 1) in the two soil types played a role in the rhizobiome bacterial diversity, as unique OTUs could be identified in all respective rhizosphere soil samples. There was, however, also a large overlap in bacterial diversity in the different soil types and in the rhizobiome of the three plant species. Soil type also played a significant role in the bacterial functional groups, with anaerobic respiration only being reported in the Sterkspruit soil.

\section{Acknowledgements}

The University of the Free State (UFS) Strategic Research Fund is acknowledged for funding the multidisciplinary research. Mercia Coetzee (Central University of Technology, Bloemfontein, South Africa) is thanked for her technical support in the field. Eddie Riddell and Navashni Govender (SANParks) are acknowledged for their research support in the Kruger National Park. Dr Jan-G Vermeulen (Microbial Biochemical and Food Biotechnology Department, University of the Free State, Bloemfontein, South Africa) is thanked for his assistance with graphics.

\section{Competing interests}

The authors declare that they have no financial or personal relationships that may have inappropriately influenced them in writing this article.

\section{Authors' contributions}

M.V., E.D.C. and W.J.S. contributed equally to this article. The authors directly participated in the study design, execution and interpretation of the research.

\section{Funding information}

This research received no specific grant from any funding agency in the public, commercial or not-for-profit sectors.

\section{Data availability}

Data sharing is not applicable to this article as no new data were created or analysed in this article.

\section{Disclaimer}

The views and opinions expressed in this article are those of the authors and do not necessarily reflect the official policy or position of any affiliated agency of the authors.

\section{References}

Andrews, S., 2010, FastQC: A quality control tool for high throughput sequence data, viewed 01 July 2019, from http://www/bioinformatics.babraham.ac.uk/projects/ fastqc.

Bachman, G. \& H. Kinzel., 1992, 'Physiological and ecological aspects of the interactions between plant roots and rhizosphere soil', Soil Biology and Biochemistry 24(6), 5543-5552. https://doi.org/10.1016/0038-0717(92) 90079-D

Bardgett, R.D., Bowman, W.D. Kaufmann, R. \& Schmidt, S.K., 2005, 'A temporal approach to linking aboveground and belowground ecology', Trends in Ecology and Evolution 20(11), 634-641. https://doi.org/10.1016/j.tree.2005.08.005

Berg, G. \& Smalla, K., 2009, 'Plant species and soil type cooperatively shape the structure and function of microbial communities in the rhizosphere', FEMS Microbial Ecology 68(1), 1-13. https://doi.org/10.1111/j.1574-6941. 2009.00654.x

Bonkowski, M., Cheng, W., Griffiths, B.S., Alphei, J. \& Scheu, S., 2000, 'Microbial-faunal interactions in the rhizosphere and effects on plant growth', European Journal of Soil Biology 36(3-4), 135-147. https://doi.org/10.1016/S1164-5563(00)01059-1

Bonkowski, M., Villenave, C. \& Griffiths, B., 2009, 'Rhizosphere fauna: The functional and structural diversity of intimate interactions of soil fauna with plant roots', Plant Soil 321, 213-233. https://doi.org/10.1007/s11104-009-0013-2 
Bouwer, D., Le Roux, P.A.L. \& Van Tol, J., 2020, 'Identification of hydropedological flowpaths in Stevenson-Hamilton catena from soil morphological, chemical and hydraulic properties', Koedoe 62(2), a1584. https://doi.org/10.4102/koedoe. v62i2.1584

Bulgarelli, D., Schlaeppi, K., Spaepen, S., Ver Loren van Themaat, E. \& Schulze-Lefert, P., 2013, 'Structure and functions of the bacterial microbiota of plants', Annual Review of Plant Biology 64, 807-838. https://doi.org/10.1146/annurevarplant-050312-120106

Caporaso, J.G., Kuczynski, J., Stombaugh, J., Bittinger, K., Bushman, F.D. \& Costello, E.K. et al., 2010, 'OllME allows analyses of high-throughput community sequencing data', Nature Methods 7, 335-336. https://doi.org/10.1038/nmeth.f.303

Carruthers, J., 2017, National park science: A century of research in South Africa (Ecology, Biodiversity and Conservation), Cambridge University Press, Cambridge.

Doornbos, R.F., Van Loon, L.C. \& Bakker, P.A.H.M., 2012, 'Impact of root exudates and plant defence signalling on bacterial communities in the rhizosphere: A review',
Agronomy for Sustainable Development 32, 227-243. https://doi.org/10.1007/ Agronomy for Sustain
s13593-011-0028-y

Edgar, R.C., 2010, 'Search and clustering orders of magnitude faster than BLAST', Bioinformatics 26(19), 2460-2461. https://doi.org/10.1093/bioinformatics/btq461

Fierer, N. \& Jackson, R.B., 2006, 'The diversity and biogeography of soil bacterial communities', Proceedings of the National Academy of Sciences of the United States of America 103(3), 626-631. https://doi.org/10.1073/pnas.0507535103

Fuerst, J.A., 1995, 'The planctomycetes - Emerging models for microbial ecology, evolution and cell biology', Microbiology 141(7), 1493-1506. https://doi org/10.1099/13500872-141-7-1493

Gkarmiri, K., Mahmood, S., Ekblad, A., Alström, S., Högberg, N. \& Finlay, R., 2017, 'Identifying the active microbiome associated with roots and rhizosphere soil of oilseed rape', Applied and Environmental Microbiology 83(22), e01938-17. oilseed rape, Applied and Environment
https://doi.org/10.1128/AEM.01938-17

Gryzenhout, M., Cason, E.D., Vermeulen, M., Kloppers, G.A.E., Bailey, B. \& Ghosh, S. 2020, 'Fungal community structure variability between the root rhizosphere and endosphere in a granite catena system in Kruger National Park, South Africa', Koedoe 62(2), a1597. https://doi.org/10.4102/koedoe.v62i2.1597

Haichar, F.E.Z., Santaella, C., Heulin, T. \& Achouak, W., 2014, 'Root exudates mediated interactions belowground', Soil Biology and Biochemistry 77, 69-80. https://doi org/10.1016/j.soilbio.2014.06.017

Helliwell, J.R., Sturrock, C.J., Miller, A.J., Whalley, W.R. \& Mooney, S.J., 2019, 'The role of plant species and soil condition in the structural development of the rhizosphere', Plant Cell and Environment 42(6), 1974-1986. https://doi org/10.1111/pce.13529

Hiltner, L., 1904, 'Uber neuere Erfahrungen und Probleme auf dem Gebiete der Bodenbakteriologie unter besonderden berucksichtigung und Brache', Arbeiten der Deutschen Landwirtschaftlichen Gesellschaf 98, 59-78.

Janecke, B.B., Van Tol, J., Smit, I.P.J., Van Aardt, A.C., Riddell, E.S., Seaman, M.T. et al., 2020, 'Biotic and abiotic connections on a granitic catena: Framework for multidisciplinary research', Koedoe 62(2), a1600. https://doi.org/10.4102/ koedoe.v62i2.1600

Janssen, P.H., 2006, 'Identifying the dominant soil bacterial taxa in libraries of $16 S^{\prime}$ rRNA and 16S rRNA genes', Applied and Environmental Microbiology 72(3), 1719-1728. https://doi.org/10.1128/AEM.72.3.1719-1728.2006

Lauber, C.L., Hamady, M., Knight, R. \& Fierer, N., 2009, 'Pyrosequencing- based assessment of soil $\mathrm{pH}$ as a predictor of soil bacterial community structure at the continental scale', Applied and Environmental Microbiology 75(15), 5111-5120. https://doi.org/10.1128/AEM.00335-09

Leff, J.W., Jones, S.E., Prober, S.M., Barberan, A., Borer, E.T. \& Firn, J.L. et al., 2015 'Consistent response of soil microbial communities to elevated nutrient inputs in grasslands across the globe', Proceedings of the National Academy of Sciences of grasslands across the globe, Proceedings of the National Academy of Sciences of
the United States of America 112(35), 10967-10972. https://doi.org/10.1073/ the United States
pnas.1508382112

Levick, S.R., Asner, G.P., Chadwick, O.A., Khomo, L.M., Rogers, K.H. \& Hartshorn, A.S. et al., 2010, 'Regional insight into savanna hydrogeomorphology from termite mounds', Nature Communications 1, 65. https://doi.org/10.1038/ncomms1066

Louca, S., Parfrey, L.W. \& Doebeli, M., 2016, 'Decoupling function and taxonomy in the global ocean microbiome', Science 353(6305), 1272-1277. https://doi. org/10.1126/science.aaf4507

Lozupone, C.A., McDonald, D., Muegge, B.D., Pirrung, M., Reeder, J. \& Sevinsky, J.R. et al., 2010, 'QlIME allows analyses of high-throughput community sequencing data', Nature Methods 7, 335-336. https://doi.org/10.1038/nmeth.f.303

Marschner, P., Yang, C.H., Lieberei, R. \& Crowley, D.E., 2001, 'Soil and plant specific effects on bacterial community composition in the rhizosphere', Soil Biology and
Biochemistry 33(11), 1437-1445. https://doi.org/10.1016/S0038-0717(01)00052-9

McMurdie, P.J. \& Holmes, S., 2013, 'Phyloseq: An R package for reproducible interactive analysis and graphics of microbiome census data', PLOS One 8(4), e61217. https://doi.org/10.1371/journal.pone.0061217

Myers, R.T.M., Zak, D.R., White, D.C. \& Peacock, A., 2001, 'Landscape-level patterns of microbial community composition and substrate use in upland forest ecosystems' Soil Science Society of America Journal 65(2), 359-367. https://doi.org/10.2136/ sssaj2001.652359x

Nacke, H., Thürmer, A., Wollherr, A., Will, C., Hodac, L. \& Herold, N. et al., 2011, 'Pyrosequencing-based assessment of bacterial community structure along different management types in german forest and grassland soils', PLoS One 6(2), e17000. https://doi.org/10.1371/journal.pone.0017000

Oksanen, J., Blanchet, F.G., Kindt, R., Legendre, P., Minchin, P.R. \& O'Hara, R.B. et al., 2013, Vegan: Community ecology package, R package version $2.0-2,01$ viewed July 2019, from http://CRAN.R-project.org/package=vegan.
Pallela, P.N.V.K., Ummey, S., Ruddaraju, L.K., Pammi, S.V.N. \& Yoon, S.-G., 2018, 'Ultra small, mono dispersed green synthesized silver nanoparticles using aqueous extract of Sida cordifolia plant and investigation of antibacterial activity', Microbial Pathogenesis 124, 63-69. https://doi.org/10.1016/j.micpath.2018.08.026

Philippot, L., Raaijmakers, J.M., Lemanceau, P. \& Van der Putten, W.H., 2013, 'Going back to the roots: The microbial ecology of the rhizosphere', Nature Review Microbiology 11(11), 789-799. https://doi.org/10.1038/nrmicro3109

Prober, S.M., Leff, J.W., Bates, S.T., Borer, E.T., Firn, J. \& Harpole, W.S. et al., 2015, 'Plant diversity predicts beta but not alpha diversity of soil microbes across grasslands worldwide', Ecology Letters 18(1), 85-95. https://doi.org/10.1111/ ele.12381

Raaijmakers, J.M., Paulitz, T.C., Steinberg, C., Alabouvette, C. \& Moenne-Loccoz, Y., 2009, 'The rhizosphere: A playground and battlefield for soilborne pathogens and beneficial microorganisms', Plant Soil 321, 341-361. https://doi.org/10.1007/ s11104-008-9568-6

Rughöft, S., Herrmann, M., Lazar, C.S., Cezar, S., Levick, S.R. \& Trumbore, S.E. et al., 2016, 'Community composition and abundance of bacterial, archaeal and nitrifying populations in Savana soils of contrasting bedrock material in Kruger National Park, South Africa', Frontiers in Microbiology 7, 1638. https://doi. org/10.3389/fmicb.2016.01638

Sandoval-Denis, M., Swart, W.J. \& Crous, P.W., 2018, 'New Fusarium species from the Kruger National Park, South Africa', MycoKeys 34, 63-92. https://doi.org/10.3897/ mycokeys.34.25974

Schmieder, R. \& Edwards, R., 2011, ‘Quality control and preprocessing of metagenomic datasets', Bioinformatics 27(6), 863-864. https://doi.org/10.1093/bioinformatics/ btr026

Singh, B.K., Millard, P., Whiteley, A.S. \& Murrell, J.C., 2004, 'Unravelling rhizospheremicrobial interactions: Opportunities and limitations', Trends in Microbiology 12(8), 386-393. https://doi.org/10.1016/j.tim.2004.06.008

Smit, I.P.J., Riddell, S.E., Cullum, C. \& Petersen, R., 2013, 'Kruger National Park research supersites: Establishing long-term research sites for cross-disciplinary, multiscaled learning', Koedoe 55(1), 1107. https://doi.org/10.4102/koedoe.v55i1.1107

Sørensen, J., 1997, 'The rhizosphere as a habitat for soil microorganisms', in J.D. Van Elsas, J.T. Trevors \& E.M.H. Wellington (eds.), Modern soil microbiology, pp. 21-45, Marcel Dekker Inc., New York, NY.

Strous, M., Fuerst, J.A., Kramer, E.H.M., Logemann, S., Muyzer, G. \& Van de PasSchoonen, K.T. et al., 1999, 'Missing lithotroph identified as new planctomycete', Nature 400, 446-449. https://doi.org/10.1038/22749

Team RDC, 2011, 'R: A language and environment for statistical computing', $R$ Foundation for Statistical Computing, viewed 01 July 2019, from http://www.Rproject.org/.

Thangavel, M., Raveendran, M. \& Kathirvel, M., 2006, 'A comparative study on the effect of plant extracts with the antibiotics on organisms of hospital origin', Ancient Science of Life 26(1), 65-72.

Theron, E., Van Aardt, A.C. \& Du Preez, P.J., 2020, 'Vegetation distribution along a granite catena, southern Kruger National Park', Koedoe 62(2), a1588. https://doi. org/10.4102/koedoe.v62i2.1588

Van der Putten, W.H., Klironomos, J.N. \& Wardle, D.A., 2007, 'Microbial ecology of biological invasions', The ISME Journal 1, 28-37. https://doi.org/10.1038/ ismej.2007.9

Wang, Y., Ji, H. \& Gao, C., 2016, 'Differential response of soil bacterial taxa to longterm $\mathrm{P}, \mathrm{N}$ and organic manure application', Journal of Soils and Sediments 16 , 1046-1058. https://doi.org/10.1007/s11368-015-1320-2

Wieland, G., Neumann, R. \& Backhaus, H., 2001, 'Variation of microbial communities in soil, rhizosphere, and rhizoplane in response to crop species, soil type, and crop development', Applied and Environmental Microbiology 67(12), 5849-5854. https://doi.org/10.1128/AEM.67.12.5849-5854.2001

Yan, N., Marschner, P., Cao, W., Zuo, C. \& Qina, W., 2015, 'Influence of salinity and water content on soil microorganisms', International Soil and Water Conservation Research 3(4), 316-23. https://doi.org/10.1016/j.iswcr.2015.11.003

Zak, J.C., Willig, M.R., Moorhead, D.L. \& Wildman, H.G., 1994, 'Functional diversity of microbial communities: A quantitative approach', Soil Biology and Biochemistry 26(9), 1101-1108. https://doi.org/10.1016/0038-0717(94)90131-7

Zeng, M., Zhong, Y., Cai, S. \& Diao, Y., 2018, 'Deciphering the bacterial composition in the rhizosphere of Baphicacanthus cusia (NeeS) Bremek', Scientific Reports 8 , 15831. https://doi.org/10.1038/s41598-018-34177-1

Zhalnina, K., Dias, R., De Quadros, P.D., Davis-Richardson, A., Camargo, F.A. \& Clark, I.M. et al., 2015, 'Soil pH determines microbial diversity and composition in the park grass experiment', Microbial Ecology 69, 395-406. https://doi.org/10.1007/ p00248-014-0530-2

Zhang, J., Kobert, K., Flouri, T. \& Stamatakis, A., 2014, 'PEAR: A fast and accurate illumina paired-end read merger', Bioinformatics 30(5), 614-620. https://doi. illumina paired-end read merger',
org/10.1093/bioinformatics/btt593

Zhang, X.W., Qu, Y.Y., Ma, Q., Li, S.Z., Dai, C.X. \& Lian, S.Y. et al., 2019, 'Performance and microbial community analysis of bioaugmented activated sludge system for indigo production from indole', Applied Biochemistry and Biotechnology 187, indigo production from indole', Applied Biochemistry and
1437-1447. https://doi.org/10.1007/s12010-018-2879-z

Zhou, D., Jing, J., Chen, Y., Wang, F., Qi, D. \& Feng, R. et al., 2019, 'Deciphering microbial diversity associated with Fusarium wilt-diseased and disease-free banana rhizosphere soil', BMC Microbiology 19, 161. https://doi.org/10.1186/ s12866-019-1531-6 